\title{
Relation Between Maternal and Infant Blood Folate Activities
}

\author{
M. J. LANDON and A. OXLEY \\ From the Department of Child Health, University of Newcastle-upon-Tyne
}

Landon, M. J., and Oxley, A. (1971). Archives of Disease in Childhood, 46, 810. Relation between maternal and infant blood folate activities. The relation between maternal and cord blood folate activity was investigated in a group of 110 primigravidae and their infants. Approximately half of these mothers had received folic acid supplements during their pregnancy, and the effects of this on infant blood folate levels at birth and at 6 weeks were also studied.

In unsupplemented pregnancies there was a significant relation between infant and maternal blood folate levels at delivery.

The results of folic acid supplementation during pregnancy were reflected by higher cord blood values, but 6 weeks after delivery infant plasma folate levels were essentially the same in both groups and independent of maternal supplies before delivery.

The increasing use of microbiological assays for the estimation of blood folate levels during pregnancy has established that at term both plasma and erythrocyte folate activities are frequently below the normal levels found in nonpregnant women (Hansen, 1964; Ball and Giles, 1964; Chanarin, Rothman, and Berry, 1965).

Despite these low levels, folic acid deficiency does not appear to be a feature of the fetus because cord blood values are invariably higher than maternal levels (Baker et al., 1958, 1960; Grossowicz et al., 1960).

Grossowicz and his co-workers (1960) noted the possibility of an association between low blood folate activity in the mother and a comparatively low blood folate activity in the cord blood. Roberts et al. (1969) in a series of 20 premature infants found a similar relation with regard to erythrocyte folate activity, though in this series the mothers had been receiving prophylactic folic acid since their first antenatal attendance.

This present study investigates the relation between maternal and cord blood folate activities and the effect of the latter on infant folate status six weeks after delivery.

\section{Material}

The subjects were 110 primigravidae who, as part of another investigation (Jones, 1969), were being carefully supervised during pregnancy. As a group they had the advantage that their folate stores could not have been affected by a previous pregnancy.

Received 13 May 1971.
Experience suggested that about $50 \%$ of these patients might be expected to receive prophylactic folic acid during their pregnancy and so the opportunity was taken to see what effect this treatment might have on the maternal and cord blood haematology. 58 patients dide not receive any supplemental folic acid (Group A) in contrast to the remaining 52 who did (Group B). Of Group B, all but 7 were treated before 35 weeks, while the amount of folic acid received varied according to the different regimens adopted by the consultants in charge.

Thirty-eight infants of these women were seen at a routine post-natal clinic 6 weeks after delivery and on this occasion a heel stab blood sample was collected into EDTA for the estimation of plasma folate activity.

\section{Methods}

A cord blood sample was collected into EDTA and a maternal venous specimen was taken within 24 hours of delivery. The haemoglobin concentration, packed cell volume, white cell count, and platelet count were measured by standard methods (Dacie and Lewis, 1963).

Folate activities were assayed by the 'aseptic addition' method (Herbert, 1966) using a commercial medium (Difco) with $L$. casei var. rhamnosus (N.C.I.B. 6375) as test organism. It has been established that EDTA does not affect the assay (Herbert, 1966; Vanier and Tyas, 1966).

Haemolysates for the estimation of whole blood folate activity were prepared by the addition of $0.1 \mathrm{ml}$ whole blood to $0.9 \mathrm{ml}$ ion free water. Ascorbic acid was not used in the storage of these specimens nor were they incubated before assay. Though haemolysis in aqueous solution was used, this procedure gave results which 
bore a consistent relation to the results obtained when the more standard technique of haemolysis in ascorbate solution (Hoffbrand, Newcombe, and Mollin, 1966) was used, and therefore this modification does not affect the validity of the results (Fig. 1).

Values for cord whole blood folate levels obtained using aqueous haemolysis were comparable with other published results on this type of material (Strelling et al., 1966; Vanier and Tyas, 1967; Roberts et al., 1969).

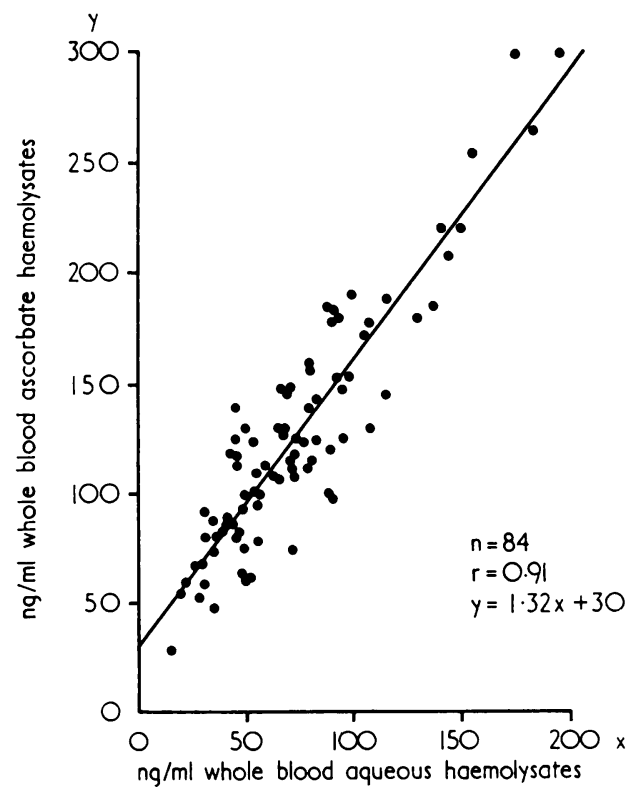

Fig. 1.-Comparison of aqueous and ascorbate haemolysates of 84 primagravida at 30 weeks' gestation.

Erythrocyte folate activity was calculated from the whole blood folate activity by correcting the latter for plasma folate and packed cell volume using the formula: $\mathbf{R B C F}=\mathrm{WBF}-\mathrm{PF}(1-(\mathrm{PCV} / 100) /(\mathrm{PCV} / 100))$

Applying this correction gave a value for erythrocyte folate activity approximately double that of whole blood folate activity, but the correlation using this correction between the whole blood folate and the erythrocyte folate was so high $(+0.98)$ that the correc- tion was ignored and only the whole blood folate levels were considered in the final analysis. It does not follow from this that the calculation of erythrocyte activity is always unnecessary nor can it be assumed that the direct and very close relation shown here between whole blood folate and erythrocyte folate activity always holds true whatever the material. The principal factor in the calculation is the packed cell volume of the sample. In the material under study the standard deviation of the packed cell volume did not exceed $5 \%$ in any of the groups considered (Table II). The comparatively small range of packed cell volume within these groups obviously makes the correction superfluous.

After 18 to 20 hours incubation at $37^{\circ} \mathrm{C}$ the growth of $L$. casei was measured turbidimetrically in an S.P. 600 spectrophotometer at $655 \mathrm{~nm}$ using an S.P. 625 flow through cell. At this wavelength the optical density of the medium is at a minimum, and any interference by haemoglobin pigments during the assay of whole blood folates can be ignored.

\section{Results}

Not unexpectedly the folate levels of those patients receiving folic acid were significantly higher at term than of those who did not. This difference between the two groups was also apparent in the cord blood values (Table I).

In the group that did not receive folic acid supplements during pregnancy (Group A) there was a significant correlation between maternal plasma folate and cord plasma folate, and also between the corresponding whole blood folate activities (Fig 2 and 3).

Within this group no significant correlations were established between either of the folate activities and either haemoglobin or packed cell volume. This was true of both the cord blood values and the maternal delivery sample. Furthermore, there was no significant correlation between the cord plasma or whole blood folate activities and the infant's birthweight.

Apart from the folate activities there were no significant differences between the two groups (Table II).

The cord blood folate levels of both groups were

TABLE I

Effect of Prophylactic Folic Acid on Maternal and Cord Blood Folate Values

\begin{tabular}{|c|c|c|c|c|c|c|}
\hline & Group & No. & Minimum & Mean & Maximum & SD \\
\hline $\begin{array}{l}\text { Maternal plasma } \mathrm{ng} / \mathrm{ml} \text { folate } \\
\text { Maternal whole blood folate } \mathrm{ng} / \mathrm{ml} \\
\text { Cord plasma folate } \mathrm{ng} / \mathrm{ml} \\
\text { Cord whole blood folate } \mathrm{ng} / \mathrm{ml}\end{array}$ & $\begin{array}{l}\text { A } \\
\text { B } \\
\text { A } \\
\text { B } \\
\text { A } \\
\text { B } \\
\text { A } \\
\text { B }\end{array}$ & $\begin{array}{l}54 \\
50 \\
54 \\
50\end{array}$ & $\begin{array}{r}1 \cdot 3 \\
4 \cdot 8 \\
14 \cdot 0 \\
38 \cdot 0 \\
4 \cdot 8 \\
10 \cdot 0 \\
130 \\
213\end{array}$ & $\begin{array}{c}3 \cdot 4 \\
26 \cdot 0 \\
44 \cdot 0 \\
298 \\
15 \cdot 1 \\
56 \cdot 6 \\
273 \\
576\end{array}$ & $\begin{array}{c}14 \cdot 8 \\
100 \cdot 0 \\
125 \cdot 0 \\
770 \\
30 \cdot 5 \\
100 \\
550 \\
1,000\end{array}$ & $\begin{array}{r}2 \cdot 6 \\
19 \cdot 5 \\
17 \cdot 5 \\
149 \\
3 \cdot 5 \\
32 \cdot 6 \\
135 \\
240\end{array}$ \\
\hline
\end{tabular}


TABLE II

Haematological Indices and Birthweights

\begin{tabular}{|c|c|c|c|c|c|c|}
\hline & Group & No. & Minimum & Mean & Maximum & SD \\
\hline $\begin{array}{l}\text { Cord } \mathrm{Hb} \\
\text { Cord PCV } \\
\text { Cord white cell count } / \mathrm{mm}^{3} \\
\text { Cord platelet count } / \mathrm{mm}^{3} \\
\text { Birthweight (g) } \\
\text { Maternal delivery } \mathrm{Hb} \\
\text { Maternal delivery } \mathrm{PCV}\end{array}$ & $\begin{array}{l}\text { A } \\
\mathbf{B} \\
\mathbf{A} \\
\mathbf{B} \\
\mathbf{A} \\
\mathbf{B} \\
\mathbf{A} \\
\mathbf{B} \\
\mathbf{A} \\
\mathbf{B} \\
\mathbf{A} \\
\mathbf{B} \\
\mathbf{A} \\
\mathbf{B}\end{array}$ & $\begin{array}{l}50 \\
50 \\
43 \\
43 \\
47 \\
50 \\
50\end{array}$ & $\begin{array}{r}88 \% \\
92 \% \\
40 \% \\
44 \% \\
1,200 \\
1,000 \\
52,000 \\
70,000 \\
2,410 \\
1,730 \\
62 \% \\
54 \% \\
25 \% \\
27 \%\end{array}$ & $\begin{array}{r}113 \% \\
113 \% \\
53 \% \\
53 \% \\
6,500 \\
6,500 \\
174,000 \\
177,000 \\
3,147 \\
3,232 \\
79 \% \\
77 \% \\
36 \% \\
37 \%\end{array}$ & $\begin{array}{r}130 \% \\
132 \% \\
61 \% \\
64 \% \\
12,200 \\
13,800 \\
350,000 \\
295,000 \\
3,969 \\
4,281 \\
91 \% \\
92 \% \\
41 \% \\
45 \%\end{array}$ & $\begin{array}{c}10 \% \\
10 \% \\
5 \% \\
4 \% \\
2,600 \\
2,600 \\
59,000 \\
56,000 \\
397 \\
482 \\
7 \cdot 4 \% \\
7 \cdot 0 \% \\
3 \cdot 9 \% \\
4 \cdot 0 \%\end{array}$ \\
\hline
\end{tabular}

Hb. $100 \%=14.4 \mathrm{~g} \mathrm{Hb} / 100 \mathrm{ml}$.

considerably higher than the corresponding maternal sample. This high level was not maintainedin the small group of infants investigated at 6 weeks all showed a fall in plasma folate activity. The fall was greatest in those whose mothers had received folic acid during pregnancy (Table III).

As shown in Fig. 4, the higher the original cord blood plasma folate activity the greater the subsequent fall in plasma folate activity postnatally. The correlation between the cord blood value and the subsequent 'loss' was in fact very high, $r=$ $+0.99 ; \mathrm{p}=0.001$.

\section{Discussion}

It is now well established that cord blood folate

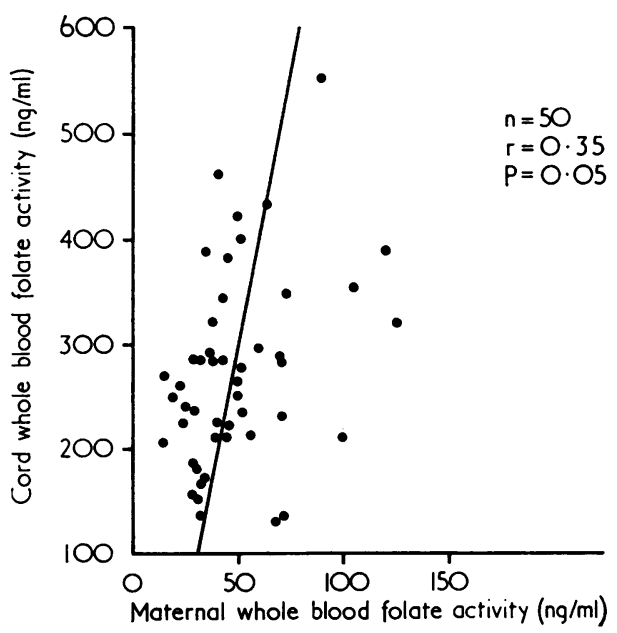

FIG. 2.-Correlation between maternal and cord whole blood folate activity. values are invariably higher than the corresponding $\infty$ maternal values. However, the present series 0 shows that despite the higher levels they are still 을

TABLE III

Plasma Folate Activity (ng/ml) in Cord Blood and at 6 Weeks After Birth

\begin{tabular}{|c|c|c|c|c|c|c|}
\hline & & No. & Minimum & Mean & Maximum & SD \\
\hline$\underset{\text { A }}{\text { Group }}$ & $\begin{array}{l}\text { Cord } \\
6 \text { wk }\end{array}$ & 17 & $\begin{array}{l}6 \cdot 5 \\
1 \cdot 0\end{array}$ & $\begin{array}{r}15 \cdot 2 \\
6 \cdot 5\end{array}$ & $\begin{array}{l}30 \cdot 5 \\
13 \cdot 0\end{array}$ & $\begin{array}{l} \pm 6 \bar{c} \\
\pm 2 z\end{array}$ \\
\hline $\begin{array}{c}\text { Group } \\
\text { B }\end{array}$ & $\begin{array}{l}\text { Cord } \\
6 \text { wk }\end{array}$ & 21 & $\begin{array}{r}10 \cdot 0 \\
3 \cdot 5\end{array}$ & $\begin{array}{l}70 \cdot 4 \\
11 \cdot 2\end{array}$ & $\begin{array}{l}100 \\
23 \cdot 0\end{array}$ & $\begin{array}{l} \pm 30 \\
\pm 5\end{array}$ \\
\hline
\end{tabular}

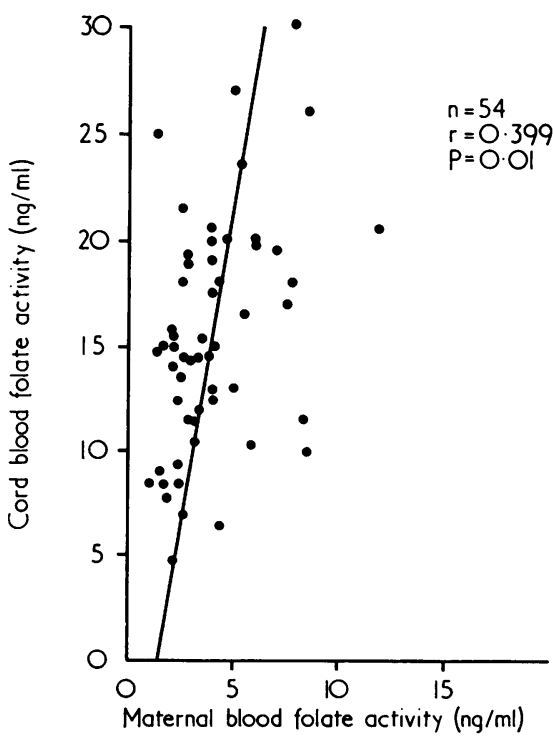

Fig. 3.-Correlation between maternal and cord blood plasma folate activity. 


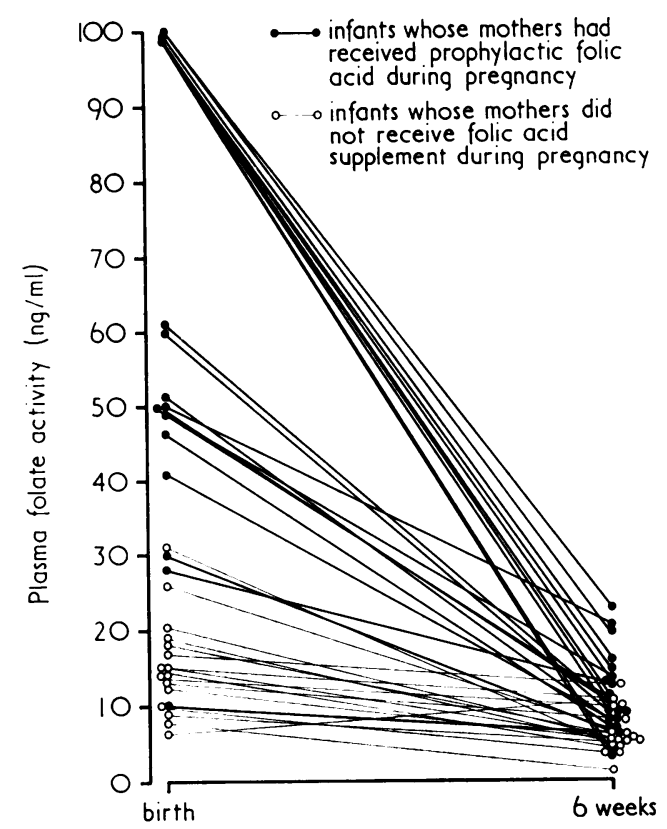

Fig. 4.-Fall in plasma folate activity after delivery.

related to the maternal supply. The exact way in which this relation is maintained is not yet clear. Recent work has tended to concentrate on the folate status of prematurity (Shojania and Gross, 1964; Strelling et al., 1966; Vanier and Tyas, 1967; Roberts et al., 1969), or on the effect of low birthweight, infections, and malnutrition (Matoth et al., 1964; Kende Ramot and Grossowicz 1963; Gray and Butler, 1965; Friedman et al., 1964). The feto-maternal relation has been further obscured in recent years by the increasing use of prophylactic folic acid during pregnancy.

Several workers have noted an association between low cord blood folate activity and birthweight in premature infants (Strelling et al., 1966; Roberts et al., 1969; Vanier and Tyas, 1967; Shojania and Gross, 1964), though Shojania and Gross (1964) said that this association did not become apparent until 6 weeks post partum. The number of short gestation (34 weeks or less) or full-term infants with a birthweight of less than $2500 \mathrm{~g}$ in the present series (10) is insufficient for any comparison to be made. However, their folate values were all within the normal range. In so far as there was no significant relation between birthweight and folate status in the present series of normal infants, it suggests that such a relation in premature infants is indirect. Roberts et al. (1969) suggested a similar unknown common cause for the correlation they found between cord haemoglobin and red cell folate in her series of premature infants. This present series does not confirm this relation for normal infants.

Both groups of infants in the present study showed a fall in plasma folate ictivity between birth and 6 weeks though the infants of mothers receiving folic acid lost comparatively more. The very high correlation between cord plasma folate activity and subsequent postnatal 'fall' suggests that 6 weeks after birth the plasma folate activities are essentially the same in both groups-and independent of maternal folic acid status. In the series investigated by Roberts and her co-workers (1969), the premature infants lost on average between $75 \%$ and $80 \%$ over the same period of time even though the cord blood values were only slightly higher than those from unsupplemented pregnancies in this present series. They claimed that the loss of folate postnatally was exponential-this is more in keeping with a 'physical decay' perhaps by excretion rather than a biological homeostatic mechanism. The relation demonstrated here between cord blood folate values and subsequent postnatal 'fall' could be similarly explained.

The finding of low folate values in infants suffering from infections, diarrhoea, and malnutrition (Gray and Butler, 1965; Matoth et al., 1964b; Friedman et al., 1964) suggests that infantile folate stores are in fact marginal. Shojania and Hornady (1970) investigated the clearance from the plasma of intravenous test doses of pteroylglutamic acid (PGA) in newborn infants and found that this was very much more rapid than that found in normal adults. In addition, large doses of PGA were required to 'saturate' the infants and bring the clearances within normal adult limits. They interpreted these results as being indicative of tissue depletion. These findings together with the drop in plasma folate post partum are not in keeping with the notion of the fetus avidly acquiring folate from maternal supplies. How then does the fetus maintain a level higher than maternal levels in utero if it cannot retain it after delivery? Grossowicz et al., (1960) using a differential microbiological assay technique suggested that cord blood was qualitatively different from maternal blood. They later found (Grossowicz, Izak, and Rachmilewitz, 1966) that even in severely anaemic folate-deficient mothers the fetus still had levels greater than the mothers even though they were below the cord blood norm. This suggests that the fetus has a very efficient supply system but a poor storage system, perhaps due to immaturity of the liver.

Preliminary investigations suggest that high folate activity in the placenta may in part be responsible 
for maintaining the fetal levels above that of the maternal supply. Lust, Hagerman, and Villee (1954) have reported that the placenta operates in this way for riboflavine.

There is no information available yet as to what part excretion plays in governing the folate status during the first few months after delivery, and it is possible that loss of folate in the urine is an important factor. Björnesjö (1968) noted that plasma amino acids like folic acid fell during pregnancy but that cord blood values were significantly higher than those of the maternal plasma. A number of workers have commented on the relative aminoaciduria in early infancy, and Woolf and Norman (1957) have suggested that tubular inefficiency is responsible. Jusko and his co-workers (1970) have recently studied the excretion of riboflavine in a small series of 5-day-old infants. They concluded that there was relatively rapid excretion of this vitamin by the neonate, primarily because of a deficiency in the tubular reabsorptive process. Goresky, Watanabe, and Johns (1963) suggested that free folate was filtered off at the glomerulus but that there was some tubular reabsorption; this was relatively sluggish with storage of folate in tubular cells thus saturating them and inhibiting further reabsorption. Initially the amount of folate excreted would depend on the fraction of plasma folates filtered off at the glomerulus. The nature and extent of the binding of folates by plasma proteins have received little attention and may be that in this respect infantile blood differs from adult blood.

The comparatively sparse information available at present suggests that the fetus plays an entirely passive role in controlling its supply of folates and that after delivery it is equally inefficient in retaining these materials.

We thank Dr. A. V. Hoffbrand for his helpful advice and criticism in the preparation of this paper.

\section{REFERENCE}

Baker, H., Frank, O., Pasher, I., Ziffer, H., and Sobotka, H. (1960). Pantothenic acid, thiamine and folic acid levels at parturition. Proceedings of the Society for Experimental Biology and Medicine, 103,321 .

Baker, H., Ziffer, H., Pasher, I., and Sobotka, H. (1958). A comparison of maternal and foetal folic acid and B12 at parturition. British Medical fournal, 1, 978.

Ball, E. W., and Giles, C. (1964). Folic acid and vitamin $B_{12}$ levels in pregnancy and their relationship to megaloblastic anaemia. fournal of Clinical Pathology, 17, 165.
Björnesjö, K. B. (1968). The distribution of amino acids between erythrocytes and plasma in fetal and maternal blood. Clinica Chimica Acta, 20, 11.

Chanarin, I., Rothman, D., and Berry, V. (1965). Iron deficiency and its relation to folic-acid status in pregnancy: result of a clinical trial. British Medical fournal, 1, 480.

Dacie, J. V., and Lewis, S. M. (1963). Practical Haematology, 3rd ed. Churchill, London; Grune and Stratton, New York.

Friedman, R., McKensie, D., Turner, T., and Wittman, W. (1964). Folic acid deficiency in infantile gastroenteritis. South African fournal of Laboratory and Clinical Medicine, 10, 69.

Goresky, C. A., Watanabe, H., and Johns, D. G. (1963). The renal excretion of folic acid. fournal of Clinical Investigation, 42, 1841 .

Gray, O. P., and Butler, E. B. (1965). Megaloblastic anaemia in premature infants. Archives of Disease in Childhood, 40, 53.

Grossowicz, N., Aronovitch, J., Rachmilewitz, M., Izak, G. Sadovsky, A., and Bercovici, B. (1960). Folic and folinic acid levels in maternal and foetal blood. British fournal of Haematology, 6, 296.

Grossowicz, N., Izak, G., and Rachmilewitz, M. (1966). The effect of anemia on the concentration of folate derivatives in paired fetal-maternal blood. Israel fournal of Medical Sciences, 2, 510.

Hansen, H. A. (1964). On the Diagnosis of Folic Acid Deficiency. p. 105. Almqvist and Wiksell, Stockholm.

Herbert, V. (1966). Aseptic addition method for Lactobacillus casei assay of folate activity in human serum. Fournal of Clinical Pathology, 19, 12.

Hoffbrand, A. V., Newcombe, B. F. A., and Mollin, D. L. (1966), Method of assay of red cell folate activity and the value of the assay as a test for folate deficiency. Fournal of Clinical Pathology, $19,17$.

Jones, P. (1969). Association between foeto-maternal bleeding and hypertension in pregnancy. British Medical fournal, 3, 738.

Jusko, W. J., Khanna, N., Levy, G., Stern, L., and Yaffe, S. J. (1970). Riboflavin absorption and excretion in the neonate. Pediatrics, 45, 945.

Kende, G., Ramot, B., and Grossowicz, N. (1963). Blood folic acid and vitamin $B_{12}$ activities in healthy infants and in infants with nutritional anaemias. British fournal of Haematology, $9,328$.

Lust, J. E., Hagerman, D. D., and Villee, C. A. (1954). The transport of riboflavin by human placenta. fournal of Clinical Investigation, 33, 38.

Matoth, Y., Zamir, R., Bar-Shani, S., and Grossowicz, N. (1964). Studies on folic acid in infancy. II. Folic and folinic acid blood levels in infants with diarrhea, malnutrition, and infection. Pediatrics, 33, 694

Roberts, P. M., Arrowsmith, D. E., Rau, S. M., and Monk-Jones, M. E. (1969). Folate state of premature infants. Archives of Disease in Childhood, 44, 637.

Shojania, A. M., and Gross, S. (1964). Folic acid deficiency and prematurity. Fournal of Pediatrics, 64, 323.

Shojania, A. M., and Hornady, G. (1970). Folate metabolism in newborns and during early infancy. Pediatric Research, 4, 422.

Strelling, M. K., Blackledge, G. D., Goodall, H. B., and Walker, C. H. M. (1966). Megaloblastic anaemia and whole-blood folate levels in premature infants. Lancet, 1, 898

Vanier, T. M., and Tyas, J. F. (1966). Folic acid status in normal infants during the first year of life. Archives of Disease in Childhood, 41, 658.

Vanier, T. M., and Tyas, J. F. (1967). Folic acid status in premature infants. Archives of Disease in Childhood, 42, 57.

Woolf, L. I., and Norman, A P. (1957). The urinary excretion of amino acids and sugars in early infancy. fournal of Pediatrics, 50, 271.

Correspondence to Mr. M. J. Landon, Attic Laboratory, Royal Victoria Infirmary, Newcastle-upon-Tyne NE1 4LP. 